\title{
Physiological Effects and Prescription of Exercise in Patients with Peripheral Artery Disease
}

\author{
Arnengsih Nazir \\ Department of Physical Medicine and Rehabilitation, Universitas Padjadjaran, Dr. Hasan Sadikin General \\ Hospital, Bandung, Indonesia
}

\begin{abstract}
Introduction: Peripheral artery disease (PAD) is a disease with atherosclerotic process in blood vessels which results in impairment of blood flow to the lower limbs. The prevalence escalates with advancing age and resulting in typical symptoms of intermittent claudication, ischemic pain at rest, non-healing wound, and atypical symptoms associated with PAD. These symptoms can lead to impaired walking, activity restrictions, and low quality of life. Regular exercise has been known as an effective intervention to reduce symptoms and improve exercise performance.

Methods: Literature published from 2011-2021 was searched using the PubMed and Google Scholar as the search engine. The keywords used were exercise, physiological effect, recommendation, peripheral artery disease, and intermittent claudication.

Results: Forty-four literature matched with the topic and 11 were used to explain sub-topics.

Conclusion: The physiological effects of regular exercise include increased of oxygen extraction from blood vessels and muscle enzyme activity, as well as decreased of inflammatory mediators associated with endothelial damage. The recommended form of exercise for PAD is walking both under supervision and without supervision at home and community. Prescription of aerobic exercise vary based on intensity targeted. Another forms of exercise recommended for PAD patients are resistance and flexibility exercises.
\end{abstract}

Keywords: exercise, peripheral artery disease, physiological effects, supervised-exercise. 


\section{ABSTRAK}

Pendahuluan: Penyakit arteri perifer (PAP) adalah penyakit dengan proses aterosklerotik pada pembuluh darah yang mengakibatkan gangguan aliran darah ke tungkai bawah. Prevalensi meningkat dengan bertambahnya usia dan menimbulkan gejala khas klaudikasio intermiten, nyeri iskemik saat istirahat, luka tidak sembuh, dan gejala-gejala atipikal yang terkait dengan PAP. Gejala-gejala ini dapat menyebabkan gangguan berjalan, pembatasan aktivitas, dan kualitas hidup yang rendah. Latihan teratur diketahui sebagai intervensi yang efektif untuk mengurangi gejala dan meningkatkan performa latihan.

Metode: Literatur yang diterbitkan antara tahun 2011-2021 dicari menggunakan PubMed dan Google Scholar sebagai mesin pencari. Kata kunci yang digunakan adalah latihan, efek fisiologis, rekomendasi, penyakit arteri perifer, dan klaudikasio intermiten.

Hasil: Empat puluh empat literatur sesuai dengan topik dan sebelas literatur digunakan untuk menerangkan sub-topik.

Kesimpulan: Efek fisiologis latihan teratur termasuk peningkatan ekstraksi oksigen dari pembuluh darah dan aktivitas enzim otot, serta penurunan mediator inflamasi yang terkait dengan kerusakan endotel. Bentuk latihan yang direkomendasikan untuk PAP adalah latihan jalan baik tersupervisi maupun tanpa supervisi di rumah atau di masyarakat. Peresepan latihan aerobik bervariasi berdasarkan intensitas yang ditargetkan. Bentuk latihan lain yang direkomendasikan untuk pasien PAP adalah latihan ketahanan dan fleksibilitas.

Kata Kunci: efek fisiologi, latihan, latihan tersupervisi, penyakit arteri perifer.

\section{Correspondent Details:}

\section{Arnengsih Nazir}

Email : arnengsih@unpad.ac.id Department of Physical and Rehabilitation Medicine, Faculty of Medicine Universitas Padjadjaran, Dr. Hasan Sadikin General Hospital Bandung, Indonesia

\section{INTRODUCTION}

Peripheral artery disease (PAD) is a major health challenge worldwide, due to an increasing trend of cases. The global prevalence of peripheral artery disease is $5.56 \%$ in persons 25 years and over. The estimated prevalence is higher in high income countries than those in lower-middle income countries $(7.37 \%$, vs $5.09 \%$ ). PAD is disease with characterized by an atherosclerotic process that will impaired blood flow to the lower limbs. ${ }^{2}$ Overall PAD prevalence increase with advancing age and it is found in 1 of 10 adults older than 70 years. ${ }^{3}$ Major risk factors for development of PAD are hypertension, diabetes mellitus, dyslipidemia, and smoking. ${ }^{1}$

Coronary artery disease (CAD) and/ or cerebrovascular disease found in approximately $61 \%$ of PAD patients. A metaanalysis of more than 48,000 participants in a cohort study showed that low ankle-brachial index (ABI) predicted a two-fold risk of death, cardiovascular death, and major coronary events. Increasing risks of cardiovascular 
events also occurs in symptomatic and asymptomatic patients. ${ }^{3}$

The health problems caused by PAD derived from the limb symptoms and cardiovascular manifestations of the atherosclerosis process. ${ }^{3}$ Comprehensive medical examination and assessment of typical symptoms of intermittent claudication (IC), ischemic pain at rest, non-healing wound, and another symptoms associated with PAD which can lead to impaired walking should be given to people with high risk of PAD. ${ }^{4}$ The limitations of walking in PAD patients derived from many factors and are shown by restriction of activities to reduce incidence of leg discomfort. Decreased walking performance in people with PAD correlates with poor clinical outcomes, and further contributes to worsening of the disease. In PAD patients, quality of life (QoL) is reduced due to pain in lower limbs and activity restrictions. ${ }^{3,5}$

The goals of PAD treatment are to relieve symptoms, increase functional capacity, and reduce risks of cardiovascular diseases. It is recommended to give supervised-exercise program for all patients to initiate rehabilitation program. $^{2}$ In patients with typical IC, supervised-exercise is effective in improving functional status, leg symptoms, and QoL. ${ }^{6}$ Exercise is beneficial for PAD patients because it causes an increase of exercise performance without changing in maximum lower limbs blood flow significantly. Exercise can also causes various physiological adaptations such as changes of metabolism or morphology of muscles and increase of muscle strength. The prescription of exercise for PAD is difficult because of high risks of cardiovascular events and the presence of multiple comorbidities, so the program must be prescribed individually and supervised by a trained healthcare professional. ${ }^{2}$ This review described the role of exercise in PAD management with a focus on the physiological effects and prescription of exercise.

\section{METHODS}

Literature related to exercise in patients with PAD and published in the last 10 years were searched with the PubMed and Google Scholar as the search engine. The keywords used were exercise, physiological effects, recommendations, peripheral arterial disease, and intermittent claudication. Literature types are original articles and/or review articles as well as book which were written in English. Literature was excluded if it was not relevant to the research topic and was not available or not accessible in full text. Outcomes summarized were the physiological effects and prescription of exercise in patients PAD.

\section{RESULTS}

Forty-four journals matched with the topic. After reading the full-text of all literature, 11 literature were used to explain subtopic. Seven literature explained about the physiological effects of exercise and 8 literature explained prescription of exercise. Four literature explained both physiological effect and prescription of exercise. Literature which were not focus in explaining both subtopics were excluded. 


\section{DISCUSSION}

\section{Peripheral Artery Disease}

Narrowing of the peripheral arteries (away from the heart) which supply the legs, stomach, arms and head is the main pathology of PAD and results in stenosis and/or blockage of the large and medium arteries, in addition to the arteries supplying blood to the heart causing CAD or the brain causing cerebrovascular disease. ${ }^{7,8}$ Patients who meet the criteria in Table 1 are at high-risk for development of PAD. ${ }^{6}$

Diagnosis of PAD made by history, physical examination, and investigations. Apart from IC, other complaints can include non-joint symptoms in the lower extremities, impaired walking function and ischemic pain at rest. The clinical features of PAD vary from the classic symptom of IC to critical limb ischemic. IC is a symptoms of fatigue, cramping, discomfort, or vascular origin pain in lower limb muscles that consistently induced by exertion and relieved by rest (within $10 \mathrm{~min}$ ). ${ }^{6}$

Clinical features of PAD can be found as a typical IC, atypical symptoms, or asymptomatic. Atypical symptoms of PAD include: (1) discomfort or pain, begins at rest and worsens with exertion; (2) discomfort or pain that does not stop a person from walking; and (3) discomfort or pain, begins with exertion and not alleviated with rest (within 10 minutes). Clinical findings suspected of PAD described in Table $2 .{ }^{6}$

Table 1. Criteria of High Risk for Development of Peripheral Artery Disease

\section{Criteria}

Age $\geq 65$ years

Age 50-64 years, with risk of atherosclerosis (e.g., hypertension, diabetes mellitus, dyslipidemia, and smoking) or family history

Age $<50$ years, with diabetes mellitus and 1 additional atherosclerotic risk factor

Individuals with known atherosclerotic disease in another vascular bed (e.g., coronary, subclavian, carotid, mesenteric, and renal artery stenosis, or aneurysm of abdominal aortic)

Table 2. Clinical Findings Suspected of Peripheral Artery Disease

\begin{tabular}{ll}
\hline History & Physical Examination \\
\hline - Intermittent claudication & - Vascular bruit \\
- Other non-joint-related lower limb symptoms on & - Non-healing wound at lower limbs \\
exertion (not typical intermittent claudication) & \\
- Impaired walking performance & - Gangrene of lower limbs \\
- Resting ischemic pain & - Other suggestive lower limbs physical findings \\
& (e.g., dependent rubor/elevation pallor) \\
\hline
\end{tabular}


Non-invasive examinations include toe- and ankle-brachial index, segmental pressure measurement, duplex ultrasound imaging, pulse volume recording, Doppler waveform analysis, and exercise testing. Non-invasive testing can objectively assess PAD status and facilitate treatment planning. These tests can be done without risk, provide prognostic data, and relatively inexpensive. The goals of noninvasive testing include objective diagnosis of PAD, quantitatively assess disease severity, localize lesions to a specific artery segments, and determine response to therapy or extension of disease. The most commonly performed non-invasive examination is the ABI. ${ }^{6}$

$\mathrm{ABI}$ is an assessment that provides data of perfusion of lower limbs artery. The cuff is attached to lower calf or ankle. Systolic blood pressure in the brachial, tibialis posterior, and dorsalis pedis arteries is detected by Handheld Doppler. In healthy individuals, due to amplification of pulse pressure, ankle pressure is higher than systolic pressure of brachial artery. The ratio of systolic blood pressure to ankle and arm is 1.0 to 1.4 . A value greater than 1.4 indicates a non-compressible artery. $\mathrm{ABI}$ values from 0.91 to 0.99 are considered "limits". The ABI value is considered to be mildly decreasing when it is less than or equal to 0.90 and greater than or equal to 0.80 , decreasing moderately between 0.50 and 0.80 , and it decreases greatly when it is less than $0.50 .^{5,6}$ Severity of PAD according to Fontaine classification are as follow: (1) stage I: asymptomatic; (2) stage IIa: IC; (3) stage IIb: pain-free, claudication walking $>200 \mathrm{~m}$; (4) stage IIb: pain-free, claudication walking $<200 \mathrm{~m}$; (5) stage III: nocturnal/rest pain; and (6) stage IV: gangrene/necrosis. ${ }^{9}$
PAD is a complex pathophysiology that causes significant limitations in functional ability and exercise performance. The mechanism that causes exercise limitation derives from a decrease of oxygen delivery or blood flow to the muscles being used in exercise. The limitation is also caused by skeletal muscle ischemia that occurs during walking exercise and reperfusion that occurs at rest. This pathophysiological condition resulting in a series of pathophysiological responses that lead to further tissue injury, endothelial dysfunction, muscle metabolic disorders, and other changes that further reduce exercise capacity. ${ }^{10}$

Complaints of the lower extremities caused PAD sufferers to experience changes in peak exercise performance that limit the ability to walk. A prospective study suggests that symptomatic or asymptomatic patients have a risk of progressive dysfunction. PAD sufferers tend to limit their physical activities to avoid complaints that further results in decreased QoL. ${ }^{3,10}$ One study has shown that people with PAD was experienced reduction of peak exercise performance by $50 \%$ compared to a healthy population of the same age. Decrease in exercise performance correlated with disturbances in daily physical activity and energy expenditure. A meta-analysis assessing walking impairment questionnaires and measuring walking time was proved that decreased in walking function correlated with increased of cardiovascular events and mortality. Low physical activity increased the progression of PAD with a decrease of $\mathrm{ABI}$ over time. ${ }^{3}$

Five-year mortality rate is $10 \%$ in patients with $\mathrm{ABI}$ value $<0.85$, and $50 \%$ in those with ABI value $<0.40 .{ }^{5}$ Clinical feature of PAD 
is possibly altered by exercise programs combined with modifications of risk factors. The goals of comprehensive strategies (including exercise) to prevent PAD are as follow: (1) to reduce symptoms of limb; (2) to prevent or lessen physical disability and increase exercise capacity; and (3) to decrease cardiovascular events. ${ }^{11}$

\section{Physiological Effects of Exercise in Peripheral Artery Disease}

Regular exercise increases extraction of oxygen from blood vessels and muscle enzyme activity, as well as reduces inflammatory mediators associated with endothelial damage. Patients who follow a regular exercise program had improved symptoms of IC and cardiovascular risks. Recommendation of first-line intervention to manage IC is supervised-exercise programs. Benefits of exercise in PAD patients and even among PAD patients without typical IC have been shown in recent studies. Exercise increased the ability to walk by an average of $150 \%$. Increased ability to walk was still seen 6 months after supervised exercise. ${ }^{5,11}$

Similar to a supervised-exercise program, in study by Gardner et al. was found that homebased exercise program had a high level of adherence and effective to improve IC. Compared to supervised-exercise program, home-based exercise program appeared to be more efficient in increasing daily ambulatory activity in the community. Home-based exercise program, with periodic feedback and monitoring can be used as a model of intervention with less effort and resources to improve IC in more patients. ${ }^{12}$

Improvement of various maladaptive responses such as endothelial dysfunction, arterial obstruction, mitochondrial dysfunction, skeletal muscle phenotype changes, and inflammatory activation that limits exercise performance in PAD patients explained the functional benefits of exercise. Exercise potentially reverse the pathological event and resulting in the following physiological effects such as: (1) minimal increase in collateral flow; (2) increases nitric oxide-dependent vasodilation; (3) increases of mitochondrial energetics; (4) increases mitochondrial biogenesis in animal models; and (5) decreases systemic inflammatory markers. ${ }^{11,13}$

Some benefits of exercise in PAD patients as found by Askew et al. are increase of $179 \%$ pain-free walking distance and $122 \%$ maximum walking distance, increase about 5 minutes of maximum walking time, change of walking capacity, change of strength and resistance of the plantar flexor muscles, increase functional capacity, and improve QoL score. Daily physical activities, as measured by self-report questionnaire and accelerometer, also increased with exercise, but requires further research. ${ }^{2}$

Resistance exercise improves walking ability in persons with PAD by a clinically meaningful extent. Better results were related to higher intensity of exercise. The physiological effects of resistance exercise in PAD are increase muscle mass and strength. Increase of muscle strength leads to greater muscle fiber recruitment during walking, so it is reduce energy cost of walking. ${ }^{14,15}$

\section{Pre-exercise Evaluation}

Before initiating a supervised exercise program all patients should undergo a complete assessment to exclude unstable cardiac disease. Patients with symptomatic 
heart disease such as myocardial infarction in the past 12 months, history of stable angina pectoris, prior coronary artery bypass graft surgery, prior coronary angioplasty or coronary stent, heart failure, heart or heart-lung transplantation, and prior heart valve repair or replacement should undergo an exercise testing. These assessment and exercise testing aims to identify whether patients need medical treatment before performing an exercise. Assessment also include identification of balance and mobility disorders, neurological diseases, and orthopedic conditions that limit exercise performance. ${ }^{14}$

Generally, the most common exercise testing performed in PAD patients is treadmill exercise testing which can be done as constant-load and graded exercise testing. Graded exercise testing is well established in clinical medicine, include in PAD. This test results in informative submaximal or maximal performance and characterizes submaximal walking endurance. In addition, this test is an accurate assessment of a wide range of exercise limitations. The 6-minute walk test has been used widely as an assessment modality, but less well studied in PAD. ${ }^{16}$

\section{Prescription of Exercise in People with Peripheral Artery Disease}

Supervised exercise programs should be individualized in patients with PAD with regard to exercise prescription. Randomized trials of supervised exercise programs demonstrated significant improvement in walking performance of patients with PAD with walking exercise 3 times a week. Intensity of exercise can be determined by percentage of maximum workload or peak oxygen consumption (VO2) attained during a treadmill exercise testing. Exercise intensity may be related to peak VO2 improvement, but may not be related to the amount of walking distance improvement. Improvement of peak VO2 was greater with vigorous intensity (70\%-80\% peak VO2) interval exercise than moderate intensity intermittent exercise. Exercise time should progress up to 30 to 45 minutes per session in treadmill walking exercise. Exercise should be done at intensity that elicits mild claudication within 5 minutes, moderate to moderately severe IC within 10 minutes, followed by rest until IC subsides. ${ }^{14}$

One of the recommendation of exercise for PAD suggested prescription of aerobic exercise using treadmill begin at a grade that induce IC within 3-5 minutes. When IC reaches a moderate level, the patient instructed to stop walking and rest. When IC subsided, the patient resumes walking until moderate IC recurs. This exercise and rest cycle repeated for a minimum 30 minutes. After few sessions, progress exercise until the patient is able to walk for $\geq 10$ minutes at a lower workload without reaching moderate IC. Exercise time $>30$ minutes per session provides greater benefit than $<30$ minutes. Exercise $>3$ sessions a week is more effective than $<3$. Program time of $>26$ weeks is more effective than $<26$ weeks. Bicycle ergometer, brisk walking, and strengthening exercise can be used as an alternatives to treadmill exercise. However, treadmill exercise have been found to be superior from static or dynamic leg exercises, stair climbing, and cycling. ${ }^{17}$ Table 3 summarized the prescription of aerobic exercise in patient with PAD.

Based on the various prescription of exercise in Table 3, it can be summarized that the frequency of aerobic exercise for PAD is at least 3 days/ 
week. The intensity can be determined by peak or maximum $\mathrm{VO} 2$, maximum heart rate, or claudication pain endpoint. Generally, exercise duration was about 30-60 min per session with modality treadmill walking. ${ }^{2,11,13,14,18,19}$ Duration of aerobic exercise program recommended by previous literature was at least 3 months. ${ }^{19}$

Resistance training consists of structured bodyweight, machine, or free-weight training. Both upper- and lower-body muscle groups may be exercised. Resistance training protocols can consist of circuit training or sets of repetitions and are often designed such that the workload is increased over the duration of the program. ${ }^{20}$ ACSM was recommended resistance and flexibility exercises as a part of rehabilitation of patients with PAD. The prescription of resistance exercise is with the frequency of a minimum 2 days/ week and not done consecutively with the intensity $60-80 \%$ of 1 RM. Exercise is given for 2-3 sets, 8-12 repetitions/set, and 6-8 repetitions for large muscle groups. Exercise applied to whole body, by large muscle groups, especially lower limbs. ${ }^{18}$ Amrosetti was recommended resistance exercise with the frequency $\geq 2$ day/week, intensity 1-3 sets of 8-15 RM for each muscle group, and modality all major muscle groups. ${ }^{13}$ Flexibility exercise recommended by ACSM is with the frequency $>2-3$ days/week by stretching muscles until slightly uncomfortable or tight, followed by holding for 10-30 seconds for static stretching with 2-4 repetitions/session. Dynamic stretching and or propioceptive neuromuscular facilitation can also be used. ${ }^{18}$

Table 3. Prescription of Aerobic Exercise in Patients with Peripheral Artery Disease

\begin{tabular}{ll}
\hline Author(s)/Year & Exercise Prescription \\
\hline Harwood et & - Frequency: $\geq 3$ days/week \\
al./2020.(19) & - Intensity: between $70 \%-90 \%$ of maximum heart rate \\
& - Duration: start with just $10-15$ min of walking exercise per session, \\
& increased by 5 min each week, until the patient is walking for at least 30 \\
& min per session. Patients who can walk for more than 30 min per session \\
& should be encouraged to increase the exercise duration to $45-60$ min. \\
& - Modality: treadmill, over-ground walking (preferably indoor and air- \\
& conditioned), and upper and lower limb ergometers \\
Treat-Jacobson et & - Frequency: at least 3 days/week \\
al./2019.(14) & Intensity: interval exercise training consisting of short intervals of exercise \\
& at a vigorous intensity (70\%-80\% of peak VO2) \\
& - Duration: $>30$ to 60 min \\
- & Modality: treadmill walking. \\
- & Frequency: $3-5$ days/week \\
& - Intensity: moderate intensity (40-59\% of maximum VO2) until severe \\
& claudication appears \\
& - Duration: $30-45$ min/day (excluding rest periods) for 12 weeks, can be \\
& increased to 60 min/day \\
& - Modality: weight bearing type (treadmill walking), intermittent exercise in \\
& a sitting position during rest periods.
\end{tabular}


Table 3. Prescription of Aerobic Exercise in Patients with Peripheral Artery Disease

\begin{tabular}{|c|c|}
\hline Author(s)/Year & Exercise Prescription \\
\hline $\begin{array}{l}\text { Ambrosetti/2016. } \\
\text { (13) }\end{array}$ & $\begin{array}{l}\text { - Frequency: } 3-5 \text { days/week } \\
\text { - Intensity: resting heart rate }+40-60 \% \text { heart rate reserve or resting peak VO2 }+ \\
\text { 40-60\% VO2 reserve } \\
\text { - Duration: } 30-60 \mathrm{~min} / \text { day } \\
\text { - Modality: treadmill, stair-climber, cycle, arm cycle ergometer, rowing, and swimming. }\end{array}$ \\
\hline $\begin{array}{l}\text { Askew et } \\
\text { al./2014.(2) }\end{array}$ & $\begin{array}{l}\text { - Frequency: } 3 \text { days/week } \\
\text { - Intensity: to the point of moderate claudication pain (e.g. } 4 \text { out of 5) } \\
\text { - Duration: progress as tolerated to } 40 \text { min, excluding rest periods } \\
\text { - Modality: interval walking. }\end{array}$ \\
\hline $\begin{array}{l}\text { Hamburg et } \\
\text { al./2011.(11) }\end{array}$ & $\begin{array}{l}\text { - Frequency: } 3-5 \text { days/week } \\
\text { - Intensity: exercise at a given work rate at which the patient experiences the } \\
\text { onset of claudication; continue walking until the patient has an ischemic } \\
\text { leg pain symptom score of mild-moderate ( } 3-4 \text { out of maximum } 5 \text { points); } \\
\text { then stop until pain completely subsides; resume exercise again at similar } \\
\text { intensity; repeat rest/exercise bouts. Progress to a higher work rate when } \\
\text { the patient is able to walk for } 8 \text { min bouts without the need to stop for leg } \\
\text { symptoms. } \\
\text { - Duration: total exercise time (including rest periods) should equal } 50 \mathrm{~min} / \\
\text { day } \\
\text { - Modality: treadmill walking. }\end{array}$ \\
\hline
\end{tabular}

$\mathrm{VO} 2$ indicates oxygen uptake

Some considerations in providing training for PAD are as follow: (1) unsupervised exercise may be useful but it is not as effective as supervised-exercise; (2) an exercise program starting with only 15 minutes / day may be given to some patients, and exercise time is gradually increased by 5 minutes in 1-2 weeks; (3) weight-bearing training can be complemented by no-weights, such as ergometer of the arms and legs; (4) non-weight training modalities or cycling can be used as a warm-up but can't be used as main exercise; (5) the optimal workto-rest ratio need to be adjusted individually; and (6) symptoms of IC can exacerbated by cold environment, therefore, longer heating may be necessary to motivate the patient to address all CVD risk factors. ${ }^{18}$

\section{Safety Issues of Exercise in Peripheral Artery Disease}

Recent studies reported exercise as a safe, effective, and low-cost program to improve walking ability of PAD patients and routine cardiac examinations are not required. A clinical study of 2876 participants with average age of 54-76 years shown that all-cause complication of exercise in PAD was 1 in 10,340 patienthour. Total of cardiac and non-cardiac events was 1 in 41,363 and 1 in 13,788 patient-hour, respectively. Exercise is contraindicated for critical limb ischemic or limb pain at rest or foot ulcers. Another absolute or relative contraindications of exercise program include unstable angina, uncontrolled arrhythmias, uncontrolled hypertension, acquired or 
advance heart block, and known obstructive coronary disease. Clinical assessment should be considered if there are signs and symptoms of heart disease such as angina or dysrhythmia, and if patient perform an exercise which is not limited by IC..$^{19,21}$

Conditions that may occur during exercise include: (1) new, progressive, or rest angina (unstable angina); (2) new, progressive, or rest dyspnea; (3) hemodynamic instability during exercise; (4) acute myocardial infarction; (5) transient ischemic attack or acute stroke; (6) new or uncontrolled cardiac arrhythmia; (7) ischemic limb pain at rest; and (8) acral (toe, foot) ulceration or gangrene. The presents of these conditions prompt to termination of exercise and referral back to the patient's clinician. ${ }^{20}$

\section{CONCLUSION}

PAD is a chronic condition with the most common symptom is IC. This complaint causes a decrease in walking performance which in turn reduce functional capacity and QoL of PAD patients. Regular exercise is known as an effective intervention to reduce symptoms and improve exercise performance. The physiological effects of regular exercise include increased oxygen extraction from blood vessels and muscle enzyme activity, as well as decreased inflammatory mediators associated with endothelial damage. In general, the recommended form of exercise for PAD is walking exercise both under supervision in the hospital and without supervision at home and community. Recommendation of exercise at initial program for all patients is supervisedexercise. Prescription of aerobic exercise vary based on intensity targeted. Another forms of exercise recommended for PAD sufferers are resistance and flexibility training. It has been reported that exercise is safe, effective, and lowcost to improve walking ability of PAD patients.

\section{REFERENCES}

1. Song P, Rudan D, Zhu Y, Fowkes FJ, Rahimi $\mathrm{K}$, Fowkes FGR, et al. Global, regional, and national prevalence and risk factors for peripheral artery disease in 2015: an updated systematic review and analysis. The Lancet Glob Health. 2019; 7(8); e1020-e30.

2. Askew CD, Parmenter B, Leicht AS, Walker PJ, Golledge J. Exercise \& Sports Science Australia (ESSA) position statement on exercise prescription for patients with peripheral arterial disease and intermittent claudication. J Sci Med Sport 2014; 17(6): 623-9.

3. Hamburg NM, Creager MA. Pathophysiology of intermittent claudication in peripheral artery disease. Circ J 2017: CJ-16-1286.

4. Abola MTB, Golledge J, Miyata T, Rha S-W, Yan BP, Dy TC, et al. AsiaPacific Consensus Statement on the Management of Peripheral Artery Disease: A Report from the Asian Pacific Society of Atherosclerosis and Vascular Disease Asia-Pacific Peripheral Artery Disease Consensus Statement Project Committee. J Atheroscler Thromb 2020: 53660.

5. Andrews KL, Wolf LL. Vascular disease. In: Cifu DX, editor. Braddom's physical medicine and rehabilitation. Philadelphia: Elsevier; 2016. p. 543-6.

6. Gerhard-Herman MD, Gornik HL, Barrett C, Barshes NR, Corriere MA, 
Drachman DE, et al. 2016 AHA/ACC guideline on the management of patients with lower extremity peripheral artery disease: executive summary: a report of the American College of Cardiology/ American Heart Association Task Force on Clinical Practice Guidelines. J Am Coll Cardiol 2017; 69(11): 1465-508.

7. American Heart Association. About Peripheral Artery Disease (PAD). 2016

8. Shu J, Santulli G. Update on peripheral artery disease: Epidemiology and evidence-based facts. Atherosclerosis 2018; 275: 379-81.

9. Hardman RL, Jazaeri O, Yi J, Smith M, Gupta R, editors. Overview of classification systems in peripheral artery disease. Seminars in interventional radiology; 2014: Thieme Med. Publishers.

10. Hiatt WR, Armstrong EJ, Larson CJ, Brass EP. Pathogenesis of the limb manifestations and exercise limitations in peripheral artery disease. Circ Res 2015; 116(9): 1527-39.

11. Hamburg NM, Balady GJ. Exercise rehabilitation in peripheral artery disease: functional impact and mechanisms of benefits. Circulation 2011; 123(1): 87-97.

12. Gardner AW, Parker DE, Montgomery PS, Scott KJ, Blevins SM. Efficacy of quantified home-based exercise and supervised exercise in patients with intermittent claudication: a randomized controlled trial. Circulation 2011; 123(5): 491-8.

13. Ambrosetti M. Advances in exercise rehabilitation for patients with Lower Extremity Peripheral Artery Disease. Monaldi Arch Chest Dis 2016; 86(1-2): 752.

14. Treat-Jacobson D, McDermott MM, Bronas UG, Campia U, Collins TC, Criqui $\mathrm{MH}$, et al. Optimal exercise programs for patients with peripheral artery disease: a scientific statement from the American Heart Association. Circulation 2019; 139(4): e10-e33.

15. Parmenter BJ, Mavros Y, Dias RR, King $\mathrm{S}$, Singh MF. Resistance training as a treatment for older persons with peripheral artery disease: a systematic review and meta-analysis. Br J Sports Med 2020; 54(8): 452-61.

16. Hiatt WR, Rogers RK, Brass EP. The treadmill is a better functional test than the 6-minute walk test in therapeutic trials of patients with peripheral artery disease. Circulation 2014; 130(1): 69-78.

17. Iso Y, Suzuki H. Exercise therapy for intermittent claudication in peripheral artery disease. E-Journal Cardiol Pract 2015; 13.

18. Harwood AE, Pymer S, Ingle L, Doherty P, Chetter IC, Parmenter B, et al. Exercise training for intermittent claudication: a narrative review and summary of guidelines for practitioners. BMJ Open Sport \& Exerc Med 2020; 6(1): e000897.

19. American College of Sports Medicine. ACSM's guideline for exercise testing and prescription: Wolters Kluwer; 2018.

20. Treat-Jacobson D, McDermott MM, Beckman JA, Burt MA, Creager MA, Ehrman JK, et al. Implementation of supervised exercise therapy for patients with symptomatic peripheral artery disease: a science advisory from the American Heart Association. Circulation 2019; 140(13): e700-e10.

21. Gommans LN, Fokkenrood HJ, van Dalen HC, Scheltinga MR, Teijink JA, Peters RJ. Safety of supervised exercise therapy in patients with intermittent claudication. J Vasc Surg 2015; 61(2): 512-8. e2. 